\title{
LANGUAGE NEEDS ANALYSIS OF STUDENTS OF ECONOMICS
}

\section{Halka Čapková ${ }^{1 凶}$, Jarmila Kroupová2}

${ }^{1 凶}$ English Department, Faculty of International Relations, University of Economics, Prague, nám. W. Churchilla 4, Praha, 130 67, Czech Republic, +420603189 152, capkova@vse.cz

${ }^{2}$ English Department, Faculty of International Relations, University of Economics, Prague, Czech Republic

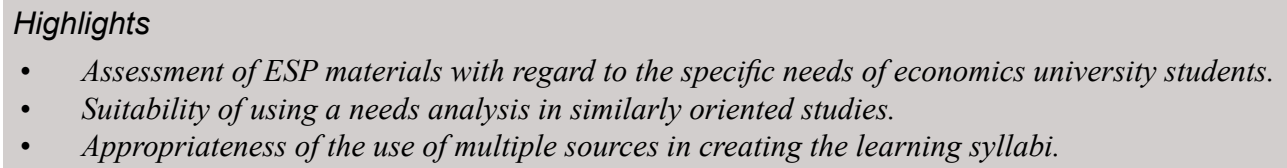

\section{Abstract}

One of the main concerns of educational specialists is the relevance of their programmes to the graduates' success on today's highly competitive labour market. As a result of these concerns academics at the English Department of the University of Economics in Prague, Czech Republic decided to conduct a survey of undergraduates, graduates and their major employers as well as the academic staff at the university in order to determine the suitability of English language courses offered to students. The result of this research has been implemented in the adaptation of new teaching materials which aim to satisfy real world requirements. A needs analysis used in this study proved to be very valuable as it emphasises the practices of using multiple sources and multiple methods in the data gathering stage. Triangulation was employed to validate the findings. This type of analysis encouraged the creation of more suitable and appropriate teaching material. Such an analysis also facilitates the collection of information regarding the needs of students and the requirements of other stakeholders.

\author{
Article type \\ Full research paper \\ Article history \\ Received: November 26, 2016 \\ Received in revised form: March 10, 2017 \\ Accepted: March 10, 2017 \\ Available on-line: April 10, 2017
}

\section{Keywords}

Coursebook, economics topics, ESP, needs analysis, questionnaire, triangulation

Čapková H., Kroupová J. (2017) “Language Needs Analysis of Students of Economics”, Journal on Efficiency and Responsibility in Education and Science, Vol. 10, No. 1, pp. 1-6, online ISSN 1803-1617, printed ISSN 2336-2375, doi: 10.7160/eriesj.2017.100101.

\section{Introduction}

English for Specific Purposes (ESP) is an area with high regard for needs analysis (Jasso-Aguilar, 2005; West, 1994) since students' needs are often rather specific and of such a nature that published textbooks would not adequately fulfil their needs. A needs analysis in broad terms can be described according to West (1994) as identifying "what learners will be required to do with the foreign language in the target situation, and how learners might best master the target language during the period of training". Therefore multiple sources and methods were used in this study to gather high quality data. The obtained data sets were then triangulated to produce credible results (JassoAguilar, 2005).

The English Department of the University of Economics in Prague has been facing a problem of course content for many years. Its students have four to six semesters of English in their bachelor's programme depending on the faculty they attend. The department offers a variety of courses ranging from general English and Cambridge English Exams preparation courses, to specialized courses tailored to the needs of the students. However, the teachers are still struggling with what the basic benchmark should be for all the students leaving the university.

Having used various textbooks focusing on business English, the textbook English for Business Studies (Cambridge Professional English by Ian MacKenzie) was finally selected for the compulsory courses due to the combination of topics covering Management, Production, Marketing, Finance and Economics. After a six-semester experience a detailed analysis revealed that although this textbook follows Williams' (1978) rule of the "wide-angle", some sections, specifically Finance (Derivatives, Accounting and financial statements, Takeovers) are too specialized for all other students not studying at the Faculty of Finance and Accounting. A subsequent elimination of the most complicated parts of the book led to internal inconsistency of the teaching material and a lack of interconnection, and therefore problems with testing. At this point, it was decided that a needs analysis would be conducted and based on the results a new teaching material tailored to the University of Economics students' needs would be created by the department members.

Despite ESP acceptance as an activity central to many English language teaching contexts, controversies and questions within ESP remain. Principal among them are the following:

1. How specific should ESP courses and texts be?

2. Should they focus upon one particular skill, e.g., reading, or should the four skills (reading, listening, writing, speaking) be always integrated?

3. Can an appropriate ESP methodology be developed?

(Johns and Dudley-Evans, 1991, p. 304)

The question of how specific ESP courses should be was raised for the first time by R. Williams (1978) when he claimed that "wide-angle" approach should be applied. It means that language and skills are taught through topics drawn from various subjects rather than from students' own discipline. This 
approach was also supported by Hutchison and Waters (1987), who in their article "English for Specific Purposes: A LearnerCentred Approach" argue that the narrow-angle approach is demotivating and irrelevant to students' needs. In particular, they claim that students should be grouped for ESP classes across broad subject areas with materials drawing from topics that give "access to a number of different specialist areas".

The authors' insight into the departments' past experience revealed that there are numerous problems connected with the choice of the suitable themes for an ESP textbook:

1. Available ESP textbooks are quite often based on previous knowledge of economics. English at the university is usually taught during the first four semesters of studies. As a consequence, students come across some of the economic topics for the first time in their English lessons.

2. The basic programme is shared by students from all faculties, which means that the ESP textbook should not be focused exclusively on, for example, finance, banking or any other economic specialisation.

3. Available Business English textbooks have quite often been used, at least partially, at secondary schools, especially the ones targeted at educating potential administrative staff who might later decide to enhance their qualifications at the University of Economics. Some of the textbooks also assume the knowledge and experience of the business environment which university students lack.

4. Apart from the economic topics, the coursebook should also offer some communicative skills and language competences essential for business communication, both written and spoken.

Therefore, the main requirement the coursebook should meet is to link economic and business English, supplemented by the most crucial communicative skills without losing the internal consistency. Another limitation that the department is facing is the length of the course (two semesters): 13 weeks per semester, 90 minutes per week, for a total of 26 weeks of teaching altogether.

The aim of this manuscript is to present one of the plausible approaches to selecting the most appropriate teaching material to satisfy students' needs via employing the basic principles of needs analysis. It may serve other academics when creating their course curriculum.

\section{Materials and Methods}

Language is generally seen as a means of filling in information gaps by present communicative methods of second or foreign language teaching. It assumes that learners can naturally develop the linguistic skills by bridging a series of information gaps (Corbett, 2003). Recent needs assessments have grown increasingly sophisticated. Therefore, materials developers have become aware of the problematic nature of their task. English for specific purposes materials designers and practitioners continue in their efforts to improve and expand their collecting and analysis techniques (Johns and Dudley-Evans, 1991, p. 299). The demand for ESP continues to increase and expand throughout the world. According to Strevens (1988) the definition of ESP needs to distinguish between absolute and variable characteristics. Absolute characteristics are:

- designed to meet specified needs of the learner

- related in content (in its themes and topics)

- centred on the language appropriate to those activities (syntax, lexis, discourse, semantics, etc. and analysis of discourse)

- in contrast with "General English".

Variable characteristics may be, but are not necessarily:

- restricted as to the language skills to be learnt (e.g., reading only)

- $\quad$ not taught according to any pre-ordained methodology.

The claims for ESP are:

- being focussed on the learner's need, wastes no time

- being relevant to the learner

- being successful in imparting learning.

As English has become a world language, the necessity to tailor the content of the textbooks to the current needs of the globalised world has risen substantially. Increasing trends toward globalisation have changed the way English is used. Currently non-native speakers need to use the language for international collaboration and business negotiations. The choice of the most suitable teaching materials is one of the crucial tasks teachers of English are facing since the needs of end-users are constantly changing.

Surveys are a popular method of collecting information on needs as they provide a flexible means of assessing the target population. In this case, multiple sources of information were used - the university students, graduates, graduates' employers, teachers and economics specialists.

\section{Students' opinion}

To start creating a coursebook for ESP students it is crucial to know what their needs for the language are. The other important input needed is what the students want and wish, what their aspirations are. For the majority of students, the primary motivation for education is career advancement. From the students' evaluations it is clear that an efficient educational programme should increase their chances of finding a job and building a successful career.

\section{Graduates' opinion}

Since the employability of our graduates is considered to be one of the most important indicators of the quality of the institution's academic performance (Ministry of Education, Youth and Sports, 2005, p. 17), it was decided to address our graduates working in various sectors of the economy in order to focus on the requirements related to the goals, aspirations and needs of the students in practice. The expected utility is to reveal the required performance skills, the most pressing needs and what knowledge, information and skills are used in practice most often.

\section{Employers' opinion}

In order to construct a profile that truly reflects the market forces, the input from major employers is required to know precisely 
what employers are looking for, what the skills and abilities allowing our graduates to be successful in the job market are, and what qualities lead to a rise on the career ladder.

To investigate our students' opinions the data from full-time students' regular course evaluations were used, especially the part with their suggestions on further improvement. It was revealed that on the one hand narrowly specialised topics such as finance, accounting, logistics, etc., were not evaluated positively, on the other hand neither were the most common topics from business English since the majority of students have already learnt them during their studies at secondary schools. There are two compulsory English courses at the University of Economics, Prague - English for Economics Studies 1 (2AJ211) and English for Economics Studies 2 (2AJ212). Every year they are attended by approximately 2,000 students each, the majority attending the 2AJ211 course in the winter semester and 2AJ212 in the summer semester. Therefore, we focused our analysis on these two respective semesters. In the winter semester 2014/15 there were 1,701 students enrolled in the course 2AJ211 and 1,489 in the $2 \mathrm{AJ} 212$ course in the summer semester. At the end of each semester the students are asked to complete an anonymous questionnaire and express their opinions on the lecturer and course they have just finished. Table 1 summarises the numbers of students in the courses and the numbers and percentages of students who completed the evaluations. The study does not reflect the aspect of gender since the evaluations are anonymous.

\begin{tabular}{|c|c|c|c|}
\hline Course & $\begin{array}{c}\text { Number of stu- } \\
\text { dents enrolled }\end{array}$ & $\begin{array}{c}\text { Number of re- } \\
\text { spondents }\end{array}$ & Percentage (\%) \\
\hline 2AJ211 & 1,701 & 787 & 46.27 \\
\hline 2AJ212 & 1,489 & 585 & 39.29 \\
\hline
\end{tabular}

Table 1: Course statistics (textbook: English for Business Studies, MacKenzie, I.), 2014-2015

The questionnaire also includes three open-ended questions whose aim is to find out what students liked and disliked about the course and what their recommendations for improvement would be. Just to mention the most frequent complaints:

- too much unknown vocabulary

- $\quad$ very bad listening sections (the authors of the textbook used non-native speakers to do the recordings)

- not enough time to study the topics in detail

- $\quad$ some topics too specialized and difficult to understand even in Czech

- not enough time for conversation.

In order to construct an appropriate teaching material it was decided to use one of the techniques recommended by literature for needs analysis - a questionnaire as it is likely to bring a representative sample allowing generalisation. According to West (1994) the use of questionnaires allows for stakeholder input, a process that is "the most common method of needs analysis". Needs analysis surveys often ask respondents to choose between various alternatives. Both ranking and rating formats are used to present the choices. Ratings allow respondents to express disinterest in all options whereas rankings require that some option be number one. In its favour, a ranking format confronts the respondents with the basic question of many needs analyses: how should various needs be ordered by importance? (McKillip, 1987, p. 72). The information gleaned from a needs analysis can be used to help define programme goals. These can then be stated as specific teaching objectives, which in turn will function as the foundation on which lesson plans, materials, tests, assignments and other activities can be developed. Basically, a needs analysis helps to clarify the purpose of the school's language programme. Moreover, the use of triangulation reduces any inaccurately perceived needs.

Two anonymous questionnaires were created to elicit the appropriate information from the university graduates and their employers. They were distributed electronically among a random sample of 1,000 graduates and 200 biggest employers. The response rate was $13.90 \%$ (139 respondents) in the case of graduates and $27.00 \%$ (54 respondents) in the case of employers. Both questionnaires have a similar structure asking about:

- the methods of testing knowledge of English during the recruitment process

- the most common situations in which English is used (written and spoken) at the workplace

- the biggest problem areas when communicating in English at work.

In the second part of the questionnaire the graduates were asked to choose the topics and skills that should create the English educational programme at the university. A wide range of topics (see Table 5) which are typically covered by various available business and economic textbooks was suggested. Moreover, the employers were asked to assess the level of English of the University of Economics graduates employed in their firms on a four point scale (excellent - sufficient - poor - insufficient).

\section{Results}

The aim of the survey carried out among the University of Economics graduates and their employers is to determine what language knowledge and skills are required when entering the labour market. Two slightly modified questionnaires were created for the target respondents - graduates and employers. The research analysis resulted in the creation of a new teaching material for the compulsory courses at the university. It had been decided that the coursebook should combine teaching economics, business and skills and therefore the questions in the survey targeted all three areas.

Closer analysis of the data revealed that the majority of employers test the applicants' knowledge of the English language as a part of their recruitment process $(94.4 \%)$, most often in the form of an interview (68.6\%). Language proficiency certificates are usually not required; however, they give their holders an advantage over other candidates. When asked about their experience with the University of Economics graduates, $82.7 \%$ found their knowledge of English sufficient, and 7.7\% found their knowledge excellent.

Table 2 summarises the data concerning the most problematic areas from the point of view of both groups of respondents:

\begin{tabular}{|l|c|c|}
\hline Problem area & Graduates (\%) & Employers (\%) \\
\hline Verbal communication & 29.50 & 46.30 \\
\hline Written communication & 10.07 & 14.81 \\
\hline Range of vocabulary & 28.06 & 22.22 \\
\hline Grammar & 21.58 & 22.22 \\
\hline Terminology & 20.86 & 38.89 \\
\hline Listening & 25.18 & 22.22 \\
\hline $\begin{array}{l}\text { Appropriate language for the level } \\
\text { of formality }\end{array}$ & 29.50 & 27.78 \\
\hline
\end{tabular}

Table 2: Major problem areas, 2015

Table 2 shows a lot of agreement in the hierarchy of the most problematic areas. Verbal communication is regarded as the weakest point in both respondent groups followed by terminology in the employers' column and appropriate language for the level of formality in the graduates' one. The scores of the grammar, listening and written communication are slightly lower in both stakeholders' groups. 
Table 3 reflects the importance of both writing and speaking skills in order of priority among graduates:

\begin{tabular}{|l|l|}
\hline Informal conversation & $86.33 \%$ \\
\hline Telephoning & $84.89 \%$ \\
\hline Negotiation/meetings & $84.17 \%$ \\
\hline Formal correspondence (e.g. proposal, application, complaint) & $81.29 \%$ \\
\hline Presentations & $78.42 \%$ \\
\hline Informal correspondence (e.g. communication with colleagues) & $77.70 \%$ \\
\hline Writing reports & $64.03 \%$ \\
\hline
\end{tabular}

Table 3: Graduates' responses, 2015

Table 4 shows the results of the same prioritisation among employers:

\begin{tabular}{|l|l|}
\hline Telephoning & $88.89 \%$ \\
\hline Presentations & $88.89 \%$ \\
\hline Negotiation/meetings & $88.89 \%$ \\
\hline Formal correspondence (e.g. proposal, application, complaint) & $83.33 \%$ \\
\hline Informal conversation & $72.22 \%$ \\
\hline Writing reports & $68.52 \%$ \\
\hline Informal correspondence (e.g. communication with colleagues) & $64.81 \%$ \\
\hline
\end{tabular}

Table 4: Employers' responses, 2015

It is obvious that the results are rather consistent and corroborate the importance and indispensability of introducing the most widely preferred activities and skills in the coursebook.

The second part of the questionnaire asks the graduates to select from a wide range of proposed topics those, they consider "basic economics" all graduates should be familiar with when leaving the university.

\begin{tabular}{|l|c|}
\hline Finance and Banking & $\mathbf{7 3 . 3 8} \%$ \\
\hline Management & $\mathbf{7 0 . 5 0} \%$ \\
\hline Marketing and Advertising & $\mathbf{6 0 . 4 3} \%$ \\
\hline International trade, Globalisation & $\mathbf{5 7 . 5 5 \%}$ \\
\hline Market structure and competition & $54.68 \%$ \\
\hline Recruitment and Employment & $\mathbf{5 1 . 8 0} \%$ \\
\hline The business cycle & $49.64 \%$ \\
\hline Intercultural communication & $\mathbf{4 8 . 9 2} \%$ \\
\hline Production, Products & $48.92 \%$ \\
\hline Government, Taxation & $\mathbf{4 8 . 9 2} \%$ \\
\hline Information about successful companies and entrepreneurs & $33.09 \%$ \\
\hline Economy and ecology & $28.06 \%$ \\
\hline Economics and its classification & $19.42 \%$ \\
\hline Corporate social responsibility, Fair Trade & $\mathbf{1 6 . 5 5 \%}$ \\
\hline Economic theories & $13.67 \%$ \\
\hline Information about significant economists & $7.19 \%$ \\
\hline
\end{tabular}

Table 5: Key economics topics, 2015

In Table 5, the topics that were finally selected to be covered in the coursebook are highlighted in bold. However, the results of the survey are only one of the factors in the decision-making process. When selecting the topics, it was essential to include the ones that are common for all the faculties at the university and their knowledge will benefit the students when starting their career in business or economics. A unanimous agreement was reached on the topics with the highest rating, such as Finance and Banking, Management, and Marketing and Advertising. Due to the limited amount of teaching hours it was necessary to narrow the total number of topics included in the material. The remaining themes were selected based on a focus group which showed the opinions of the English Department lecturers and specialists from the university departments teaching economics and business. A great emphasis was placed on the topicality and relevance of the issues. Even though Corporate social responsibility was only selected by $16.5 \%$ of respondents, it was supported by both the English teachers and the economists since it is currently in the spotlight of the public as well as specialists. Moreover, it partially overlaps with ecology.

Apart from these multiple choice questions the questionnaires comprise some open-ended questions asked with the aim of establishing the respondents' opinions on the current English teaching at the University of Economics, including their suggestions for future improvements. In the answers all the graduates put great emphasis on spoken and written communication, both formal and informal. However, although from the perspective of the user, these may seem the most burning issues, from the perspective of an English teacher it is clear that they go hand in hand with listening and reading, which really confirms the well-known fact that all four skills need to be taught and practised.

Based on the results of the analysis of the above mentioned questionnaires a team of five department members (H. Capkova, J. Kroupova, M. Kusinova, P. Novakova, Z. Siskova) created the structure of the new teaching material for the compulsory courses 2AJ211 and 2AJ212 - a two-part university coursebook English for Business and Economics. The coursebooks combine units teaching skills (formal and informal communication, presentations, formal and informal correspondence, etc.) with units that provide students with the knowledge and vocabulary of key business and economic topics, such as Management, Intercultural communication, Marketing, Government and taxation, International trade, Financial products and banking, etc.

As mentioned before the results of the survey clearly show the necessity to cover all four skills (listening, speaking, reading and writing) with the emphasis on speaking. The aim of the teaching material is to actively involve students in the process of foreign language acquisition using traditional teaching methods and a communicative style of teaching. Both coursebooks comprise a significant amount of material for vocabulary practice and enough topics to encourage discussion in class employing role play, pair work and group work. Since the classes at the university are relatively big, usually having around twenty students, it is crucial that group work is used in order to allow all students to practise speaking as much as possible. The theoretical knowledge and corresponding vocabulary inherent in each unit are practised in various case studies and business simulations based on fictitious or real situations illustrating the theme in focus, completing each unit. Most exercises focusing on practising the new vocabulary (matching, multiple gap fill, gap fill, word formation, true/false, synonyms/antonyms, etc.) also have their interactive form in the e-learning programme accompanying the whole course. Therefore, it is up to the discretion of the teacher to choose which activities are done in class and which are set for home study. These types of exercises fully correspond with the recommendations for e-learning given by the authors of the Business English Courses Online Support (Kučírková, Vogeltanzová, and Jarkovská, 2011). According to Lustigová (2012) "ICT enables a unique mixture of learning styles to enter the Business English language classroom. The teacher is challenged to identify these learning styles and then likewise has the opportunity to choose the best ones to suit the needs of individual learners"(Lustigová, 2012, p. 58). This structure reduces the monotony in class and opens a larger space for discussion, interaction and creative thinking. The main concept of the coursebook is to offer the students a variety of options to practise and improve their vocabulary, grammar, verb-noun and adjective-noun collocations, etc., and thus take responsibility for their own active learning. A teacher can choose from a wide choice of activities and create a suitable structure of the lesson.

The first part of the new coursebook was piloted in the winter semester $2015 / 16$ in the $2 \mathrm{AJ} 211$ course and the second part in the summer semester $2015 / 16$ with the same group of students. 
Table 6 shows the numbers of students in the courses and respondents in the end of course evaluations.

\begin{tabular}{|c|c|c|c|}
\hline Course & $\begin{array}{c}\text { Number of } \\
\text { students enrolled }\end{array}$ & $\begin{array}{c}\text { Number of } \\
\text { respondents }\end{array}$ & Percentage (\%) \\
\hline 2AJ211 & 1,463 & 751 & 51.33 \\
\hline 2AJ212 & 1,312 & 435 & 33.16 \\
\hline
\end{tabular}

Table 6: Course statistics (English for Business and Economics, Capkova H. and col.), 2015-2016

Feedback was collected at the end of both semesters in the form of the authors' focus group, students' course evaluations and teachers' feedback questionnaires. The overall response was largely positive, emphasising mainly the fact that the coursebook reflects the needs and aspirations of both the students and teachers. The students highly appreciated the e-learning programme accompanying the coursebook, which was tailored to assist the students in their individual preparation, offer more practice and ease the workload that must be covered in lessons. The statistics also looked at how the students perceived the courses. The numbers in Table 7 show that the majority of students $(67.12 \%$ in the course $2 \mathrm{AJ} 211$ and $56.48 \%$ in the course $2 \mathrm{AJ} 212$ ) consider the course adequately difficult. By adding together the responses in the first three rows of the overall satisfaction part (very satisfied, satisfied and quite satisfied) we obtain the percentage of satisfied students $-(90.23 \%$ in the course $2 \mathrm{AJ} 211$ and $90.69 \%$ in the course $2 \mathrm{AJ} 212$ ).

\begin{tabular}{|l|l|c|c|}
\hline & & 2AJ211 (\%) & 2AJ212 (\%) \\
\hline Difficulty & too difficult & 2.16 & 9.49 \\
\hline & difficult & 18.00 & 29.40 \\
\hline & adequate & $\mathbf{6 7 . 1 2}$ & $\mathbf{5 6 . 4 8}$ \\
\hline & easy & 11.50 & 3.94 \\
\hline & too easy & 1.22 & 0.69 \\
\hline Overall satisfaction & very satisfied & 18.72 & 17.44 \\
\hline & satisfied & $\mathbf{4 9 . 2 6}$ & $\mathbf{5 3 . 7 2}$ \\
\hline & quite satisfied & 22.25 & 19.53 \\
\hline & not satisfied & 9.36 & 6.98 \\
\hline & not satisfied at all & 0.41 & 2.33 \\
\hline
\end{tabular}

Table 7: Difficulty and overall students' satisfaction, 2016

The numbers in Table 7 refer to the evaluation of the course as a whole. It shows that on the scale from "too difficult" to "too easy" the new course is considered "adequate" by $67.12 \%$ of 2AJ211 students and $56.48 \%$ of $2 \mathrm{AJ} 212$ students. To express their overall satisfaction with the course, $49.26 \%$ of $2 \mathrm{AJ} 211$ students and $53.72 \%$ of $2 \mathrm{AJ} 212$ students were "satisfied" on the scale from "very satisfied" to "not satisfied at all". The questionnaire that students fill at the end of the course ends with open-ended questions asking students to specify what they liked and disliked about the course. Some students felt the need to assess the new coursebook. The frequently mentioned comments were:

- a lot of useful vocabulary

- $\quad$ interesting topics

- well organized coursebook

- a lot of exercises for practice

- e-learning with answer key to most exercises from the coursebook

As for the teachers, it is always difficult to reconcile with a change and some time is needed to adjust to the new conditions. However, after the initial hesitation resulting mainly from the new concept of the coursebook which assumes that lecturers approach the vast amount of material creatively and construct the structure of their lessons actively, most teachers were satisfied with the coursebooks.

Table 8 shows the overall satisfaction of teachers with the new teaching material:

\begin{tabular}{|l|c|}
\hline $\begin{array}{l}\text { How satisfied were you with using the new teaching material? } \\
\text { (on scale 1 -5) }\end{array}$ & $\%$ \\
\hline Not satisfied at all & 0 \\
\hline Not satisfied & 0 \\
\hline Quite satisfied & 36.36 \\
\hline Satisfied & 63.64 \\
\hline Very satisfied & 0 \\
\hline
\end{tabular}

Table 8: Overall teachers' opinion, 2016

Table 9 shows the summary of the results of a questionnaire distributed among the teachers using the new teaching material in their lessons (the course was taught by 12 teachers and the response rate is $91.67 \%$, which means that only 11 teachers completed the questionnaire):

\begin{tabular}{|l|c|c|}
\hline Teachers' opinions & $\begin{array}{c}\text { Yes } \\
(\%)\end{array}$ & $\begin{array}{c}\text { No } \\
(\%)\end{array}$ \\
\hline I appreciate the large amount of teaching material. & 36.36 & 63.64 \\
\hline $\begin{array}{l}\text { The topics covered correspond with the needs of } 1^{\text {st }} \text { 2 }^{\text {nd }} \text { year } \\
\text { students. }\end{array}$ & 100 & 0 \\
\hline The material is relevant to the B2 level of CEFR. & 100 & 0 \\
\hline The topics are treated well and are comprehensible for students. & 100 & 0 \\
\hline Exercises are well designed methodically. & 100 & 0 \\
\hline $\begin{array}{l}\text { There is a good balance between business and economics } \\
\text { exercises and language exercises. }\end{array}$ & 100 & 0 \\
\hline There is sufficient coverage of reading. & 100 & 0 \\
\hline There is sufficient coverage of writing. & 72.73 & 27.27 \\
\hline There is sufficient coverage of listening. & 63.64 & 36.36 \\
\hline There is sufficient coverage of speaking. & 90.91 & 9.09 \\
\hline The amount of economic terms is sufficient. & 100 & 0 \\
\hline There is sufficient coverage of grammar. & 100 & 0 \\
\hline The choice of the grammar categories covered is suitable. & 90.91 & 9.09 \\
\hline $\begin{array}{l}\text { The explanation of the grammar corresponds with the students' } \\
\text { needs. }\end{array}$ & 90.91 & 9.09 \\
\hline $\begin{array}{l}\text { The teaching material offers a sufficient amount of grammar } \\
\text { practice. }\end{array}$ & 81.82 & 18.18 \\
\hline The e-learning accompanying the material is useful. & 90.91 & 9.09 \\
\hline
\end{tabular}

\section{Table 9: Teachers' feedback, 2016}

From Table 9 it is obvious that all the teachers are fully identified with the opinions expressed in points $2-7$ plus 11 and 12 . The coverage of writing, listening and grammar $(8,9,15)$ is not completely satisfactory, moreover, the large amount of teaching material (1) is not appreciated by the majority of teachers $(63.64 \%)$. The feedback indicates that there are too many units and topics to be covered in one semester.

Due to the fact that some of the skills units do not function in practice as expected, it has been decided that one unit from each coursebook will be removed - units covering Small Talk and Telephoning skills, the main reasons being that within a ninetyminute lesson only the basics can be practised. Most of the students are at B1/B2 level and they have already mastered these basic skills. In order to improve their fluency, much more time would have to be allocated. Furthermore, in the case of telephoning, classroom practice does not reflect the real life situation very accurately.

Other changes will comprise modifications to exercises not living up to expectations, improving some reading and listening parts and replacing some of the former recordings and texts by more accurately tailored or more inspirational materials. Grammar parts accompanying each unit remain unaltered, since the majority of grammar exercises is simultaneously available in the form of e-learning. Moreover, students have access to another more complex e-learning material - the Grammar Guide.

Taking into account the opinions of students, teachers and the authors' own experience with using the material in the classroom, both cousebooks will be modified and integrated into one textbook published by the University publishing house. 


\section{Discussion}

In the case of general English it is usually sufficient to select a published English textbook at the right level and the chances are high that students' needs and expectations will be met (JassoAguilar, 2005; West, 1994). However, ESP is very different in this respect since students often learn English for work and their career may be largely dependent on how well they master the field of their interest. All language specialists consulted for this paper agree that a detailed needs analysis is the key to structuring a well-designed course. Since the University of Economics has six faculties, each specialising in a slightly different area of business and economics, Williams' (1978) "wide-angle" approach seems to be the ideal means of giving the students exactly what they need - knowledge of general business English and key economics topics that provide them with the sufficient knowledge for any direction they may wish their career to proceed in.

Literature offers a lot of examples where needs analysis is used to establish students' needs (Huhta et al, 2013). However, none represents a suitable model that could be followed successfully in the case of university students. On the other hand, it becomes absolutely evident that the more input is used, the more precise the final result is. The multiple sources covered in this analysis (undergraduates, graduates, employers, economics specialists, teachers) guarantee a realistic insight into the needs in addition to a high probability of avoiding any inaccuracies.

This paper exhibits several similarities with the project Business English Courses Online Support (Kučírková, Vogeltanzová, and Jarkovská, 2011). Even though the target group and ESP field are almost identical, the final output differs substantially. While the main objective of the above mentioned project is to create a twelve-module course in the LMS (Moodle Learning Management System), the survey in this paper is targeted at creating a new coursebook accompanied by an interactive e-learning programme with the aim of reducing the workload and also moving the teaching focus to communication, development of speaking and writing skills in the classroom. In addition to this, both studies share identical prioritisation of "focusing on the business and economic issues and suppressing the development of grammatical knowledge as the students are already supposed to have a sufficient command of English grammar appropriate for B1 level within the Common European Framework of Reference for Languages" (Kučírková, Vogeltanzová, and Jarkovská, 2011).

Our study is also inspired by the research paper by Cowling (2007) giving a detailed description of the needs analysis in the development of English language intensive courses at a Japanese industrial firm. It focuses on "the perceived needs of different informant groups, resource constraints, data gathering techniques and syllabus design..." (Cowling, 2007, p. 426). The requirements for this project were set in advance and were very specific - an intensive Business English communication course package covering from one to three years. Moreover, the target group was rather inconsistent. A multiple sources approach was used, specifically four informant groups - the sales director at the firm responsible for the language teaching contract, the client (the staff of the firm's training section), the English language instructors at the firm and the learners required to take the course. Based on this research the full syllabus was created comprising economic topics and skills, textbooks and teacher's manuals. Taking into account the specifics of the above mentioned project, it could be used exclusively as a source of inspiration and a procedure recommended for the process of the new teaching material creation.

\section{Conclusion}

Irrespective of the necessity to reduce and modify the original coursebooks, there is conclusive evidence that using the basic rules of needs analysis such as describing the target population, identifying its needs, assessing them and finally communicating the results is an effective and beneficial procedure. Not only does it address the needs of all stakeholders, it also allows advanced statistical techniques to be applied in order to develop an appropriate hierarchy of needs by combining ranking and rating formats in a questionnaire.

The English Department of the University of Economics, Prague used questionnaires as a primary research tool to determine the English language requirements of its stakeholders. A detailed analysis of the results has been used to create new teaching material for the two-semester compulsory courses of English accompanied by the e-learning programme. The research was targeted at all the major stakeholders involved in the process - students, teachers, graduates and employers. It is difficult to clearly identify students' needs. Collecting needs analysis data seems reasonably straightforward as utilising multiple sources allows for attaining useful insights into the needs of the target group. The modified version of the teaching material will serve the students of all faculties and fields of study at the University of Economics, Prague.

\section{References}

Corbett, J. (2003) An Intercultural Approach to English Language Teaching, Multilingual Matters.

Cowling, J. D. (2007) 'Needs analysis: Planning a syllabus for a series of intensive workplace courses at a leading Japanese company', English for Specific Purposes, Vol. 26, pp. 426-442. Huhta, M., Vogt, K., Johnson, E., Hall, D. R., and Tulkki, H. (2013) Needs Analysis for Language Course Design: A Holistic Approach to ESP, Cambridge: Cambridge University Press.

Hutchison, T. and Waters, A. (1987) A Learner-Centred Approach, English for Specific Purposes, Cambridge: Cambridge University Press.

Jasso-Aguilar, R. (2005) Second language needs analysis, Cambridge: Cambridge University Press.

Johns, A. M. and Dudley-Evans, T. (1991) 'English for Specific Purposes: International in Scope, Specific in Purpose', TESOL Quarterly, Vol. 25, No. 2, pp. 297-314.

Kučírková, L., Vogeltanzová, T., and Jarkovská, M. (2011) 'Business English Courses Online Support', Journal on Efficiency and Responsibility in Education and Science, Vol. 4, No. 4, pp. 197 - 206, ISSN 1803-1617.

The Long-Term Plan for Educational, Scientific, Research, Development, Artistic and Other Creative Activities of Higher Education Institutions for 2006 - 2010 (2005), Ministry of Education, Youth and Sports, Department for Higher Education Institutions, Prague.

Lustigová, L. (2012) 'ICT Challenges in the 21 $1^{\text {st }}$ Century Business English University Classroom', Journal on Efficiency and Responsibility in Education and Science, Vol. 5, No. 2, ISSN 1803-1617, (pp. 46 - 62).

McKillip, J. (1987) Need Analysis: Tools for the Human Services and Education, Newbury Park, CA: SAGE.

Strevens, P. (1988) ESP after twenty years: In M. Tickoo (ed.) A re-appraisal; ESP: state of the art, Singapore: SEAMEO Regional Language Centre.

West, R. (1994) 'Needs analysis in language teaching', Language Teaching, Vol. 27, No. 1, pp. 1-19.

Williams, R. (1978) English for Special Purposes (Special issue), MALS journal (Midlands Applied Linguistics Association), UK: The University of Birmingham. 